See discussions, stats, and author profiles for this publication at: https://www.researchgate.net/publication/320065388

\title{
Firm Performance, Corporate Governance and Executive Compensation in Pakistan
}

Article in Applied Economics · January 2018

DOI: $10.1080 / 00036846.2017 .1386277$

CITATIONS

6

3 authors:

Muhammad Fayyaz Sheikh

Government College University Faisalabad

8 PUBLICATIONS 30 CITATIONS

SEE PROFILE

Saeed Akbar

University of Bradford

38 PUBLICATIONS 552 CITATIONS

SEE PROFILE

Some of the authors of this publication are also working on these related projects:

Project International Evidence on the Determinants of Organisational Ethical Vulnerability View project

Effectiveness of Performance Appraisal View project
READS

567

Syed Zulfiqar Ali Shah

Warwick Business School

32 PUBLICATIONS 317 CITATIONS

SEE PROFILE 


\title{
Firm Performance, Corporate Governance And ExeCUTIVE COMPENSATION In PAKistan
}

\begin{abstract}
This study examines the effects of firm performance and corporate governance on chief executive officer (CEO) compensation in an emerging market, Pakistan. Using a more robust Generalized Method of Moments (GMM) estimation approach for a sample of non-financial firms listed at Karachi Stock Exchange (KSE) over the period 2005 to 2012, we find that both current and previous year accounting performance has positive influence on CEO compensation. However, stock market performance does not appear to have a positive impact on executive compensation. We further find that ownership concentration is positively related with CEO compensation, indicating some kind of collusion between management and largest shareholder to get personal benefits. Inconsistent with agency theory, CEO duality appears to have a negative influence, while board size and board independence have no convincing relationship with CEO compensation, indicating board ineffectiveness in reducing CEO entrenchment. The results of dynamic GMM model suggest that CEO pay is highly persistent and takes time to adjust to long-run equilibrium.
\end{abstract}

Key Words: Corporate Governance, Dynamic Panel, Emerging Markets, Executive Compensation, Firm Performance, Fixed Effects

Please cite this paper as:

Sheikh, M.F., Shah, S.Z.A., and Akbar, S., (2017), 'Firm Performance, Corporate Governance and Executive Compensation in Pakistan.' Applied Economics, DOI: 10.1080/00036846.2017.1386277. Forthcoming. 


\section{Introduction}

There has been an enormous growth in research on executive compensation over the last two decades with primary focus on compensation of chief executive officer (CEO). Much of this research focuses on the question whether executive compensation contracts can be justified in terms of their contribution to the firm financial performance (Devers et al., 2007, van Essen et al., 2012a). According to agency theory (Jensen and Meckling, 1976), executives are self-interested and may behave opportunistically at the expense of shareholders' interests. Therefore, corporate boards are supposed to confine executive opportunism and align the executives' interests with that of shareholders by better monitoring through effective corporate governance mechanisms, and designing efficient pay contracts that typically link executive compensation with firm performance.

The objective of this study is to examine whether CEO compensation is influenced by firm performance and corporate governance practices in an emerging market, Pakistan, where CEOs are presumed to be more powerful than the boards of directors and where family or controlling shareholders are more likely to exploit interests of minority shareholders. Specifically, this study examines the role of firm performance, board structure and concentrated/family ownership in designing CEO compensation contracts.

The Asian socio-economic and behavioral peculiarities and institutional settings are different from Western World and studies conducted in Western World have limited implications for Asian countries (Fan et al., 2011, Ghosh, 2006, Gibson, 2003, Hofstede, 1980, Sun et al., 2010, van Essen et al., 2012a). While there is some evidence on the link between firm performance, corporate governance and compensation from other Asian countries, the Pakistani context is peculiar for a number of reasons. First, concentrated and family ownership is more common in Pakistan than for 
instance, in Japan and Korea. Similarly, while Chinese firms have more ownership concentration than in Pakistan, the nature of ownership concentration in Chinese firms is different as the State usually holds high stakes in large firms (e.g., Bryson et al., 2014). On the other hand, concentrated ownership in Pakistan is maintained by non-government shareholders. Non-government ownership concentration makes firms like private owned firms which may have different implications for CEO compensation.

Second, legal and political environment in Pakistan is weaker and the overall governance is poor (Rehman et al., 2012). The government effectiveness index and regulatory quality index estimated by World Bank remained negative in the last decade or so. In addition, there is more foreign influence on governance and corporate environment. Pakistan has been under the influence of International Monetary Fund (IMF) and other funding agencies for so long. Moreover, Pakistani economy is plagued with more corruption than many other Asian countries. According to Transparency International, the Corruption Perception Index (CPI) never cross 30 for Pakistan (100 shows no corruption). Therefore, people in Pakistan (including executives) are more prone to unethical and opportunistic behavior (Mujtaba and Afza, 2011). Third, the disclosure requirement about CEO compensation is stronger in Pakistan. Companies are required to report all the components of CEO compensation. This is not the case for most of the other Asian countries (see, e.g., Basu et al., 2007, Conyon and He, 2011, Kato et al., 2007).

Given above differences, Pakistani market provides a unique context to study how the boards see firm performance as a determinant of CEO compensation? What role concentrated/family ownership plays in setting CEO pay and how board structure affects CEO compensation decisions? These questions are particularly interesting in countries like Pakistan as two seminal studies 
(Durnev and Kim, 2005, Klapper and Love, 2003) show that firm-level corporate governance practices matter more in countries with weaker legal systems and investor protection. ${ }^{1}$

Our study contributes to the extant literature in a number of ways. First, our study can be considered as a response to calls for more research on understanding how managers of emerging market firms are compensated and factors that influence these decisions (see, Fan et al., 2011, Sun et al., 2010, van Essen et al., 2012a). Fan et al. (2011), for instance, note that 'Until now, we still do not know much about how managers of emerging market firms are paid and promoted and factors that influence these decisions' (p. 211). Therefore, by analyzing CEO compensation in an emerging market of Pakistan, we provide important contribution to international literature on executive compensation.

Second, we find evidence that despite boards tend to be weaker as compared to the management in Pakistan, CEO compensation is positively associated with firms' accounting performance. This is first hand evidence in Pakistan ${ }^{2}$. Further, we find that board size and presence of non-executive directors do not contribute towards CEO compensation in any direction. This reflects the contextual settings of Pakistan where non-executive directors are hired from within the family or they are proxies of controlling shareholders, making board structure irrelevant. Contrary to agency theory arguments, we find that ownership concentration is associated with higher CEO compensation, indicating some sort of misappropriation of minority shareholders' interests. Similarly, CEO duality appears to have a negative relationship with CEO compensation. This particularly has important implication as separation of these positions has become mandatory

\footnotetext{
${ }^{1}$ Given the dominance of controlling shareholders in the developing markets, Jameson et al. (2014), for instance, call for more country level studies to better understand the influence of controlling shareholders on minority shareholders.

${ }^{2}$ Our findings are in contrast to the results of two existing studies (Kashif and Mustafa, 2012, Shah et al., 2009) on CEO compensation in Pakistan. These existing studies, however, are limited in scope and do not attempt to provide rigorous analysis.
} 
requirement in the revised Code of corporate governance in Pakistan. Overall, we highlight that corporate governance variables do not seem to influence CEO compensation in the expected directions as suggested by the agency theory.

Third, our study considers persistence and adjustment of CEO pay by examining the effect of lagged compensation on current compensation using dynamic panel model estimation. Further, bulk of the existing studies typically uses panel data estimation using fixed or random effects models. These models, however, do not control for potential endogeneity problems. Results based on these panel data models are pruned to estimation problems. As a consequence, we also employ more robust methodological procedure such as Generalized Method of Moments (GMM) that simultaneously accounts for unobserved heterogeneity, serial correlation, and endogeneity problems.

Rest of the paper is organized as follows. Literature review and hypotheses development is presented in section two. Section three describes data and methodological procedures. Section four provides empirical results while conclusions are presented in section five.

\section{Literature Review and Hypotheses}

\section{CEO Compensation and Firm Performance}

In agency theory, the corporate boards, assuming the power to look after the firm, involve in arm's length transaction with CEO and design such compensation plans which provide CEO with efficient incentives to maximize the shareholder value, and hence reduce moral hazard problem arising from separation of ownership from control (Bebchuk and Fried, 2003). This predicts a positive link between CEO compensation and firm performance. A number of studies (e.g., Bayless, 2009, Buck et al., 2008, Conyon and He, 2011, Conyon and He, 2012, Murphy, 1999, 
Ozkan, 2011) find evidence consistent with agency theory. However, there are other competing theories that emerge in response to the finding that pay-performance relationship is modest (see, Tosi et al., 2000, van Essen et al., 2012a). The most prominent one is managerial power theory (Bebchuk and Fried, 2003).

According to managerial power theory (MPT), if the balance of power shifts towards CEOs and they behave opportunistically then there is likelihood that CEOs would involve in rent extraction through setting their compensation high that is not in the interests of shareholders (Bebchuk and Fried, 2003). With increased power of CEO, the board of directors and compensation committee, under the influence of CEO, compromise their fiduciary duties and settle upon excessive CEO compensation possibly not linked to firm performance (Bebchuk and Fried, 2003).

In Pakistani context, CEOs tend to be more powerful than the boards because they are either heads of the controlling families or have strong ties with controlling shareholders (Javid and Iqbal, 2008, Kamran and Shah, 2014). The strong ties between CEOs and family/controlling shareholders suggest greater possibility of expropriation of minority shareholders' interests (Type II agency problem). In addition, the expropriation of minority shareholders' interests increases when formal institutions such as legal system and investor protection are weak. Therefore, given this context, we expect that CEO compensation contracts are not based on arm's length transaction between the board of directors and CEOs, instead these are more likely to be based on mutual interests of CEOs and controlling shareholders. Hence, we state our hypothesis that:

H1: Firm performance does not influence CEO compensation 


\section{CEO Compensation and Corporate Governance}

Corporate governance assumes the role of monitoring and curbing managerial opportunism so that shareholder's interests are protected (Fama and Jensen, 1983). As an efficient corporate governance structure provides close monitoring and oversight of management, therefore in the presence of strong corporate governance, the executive compensation would be low.

A number of corporate governance variables have been reported to influence the CEO compensation, however, their influence seems to be conditioned to the context under examination (see, e.g.,Core et al., 1999, Devers et al., 2007, Sun et al., 2010, van Essen et al., 2012b). Since concentrated and family ownership is an important feature of corporate governance environment in Pakistan and board composition has been one of the major focuses in the Code of corporate governance to mitigate the agency conflicts (see, SECP, 2002, SECP, 2012), therefore we focus on concentrated/family ownership and board structure (Board size, Board independence and CEO duality) in this study.

\section{Ownership Concentration, Family Ownership and CEO Compensation}

Concentrated and family ownership can affect CEO compensation contract in two competing ways, 1) interest alignment effect and 2) entrenchment effect. According to interest alignment effect, which relates to agency theory, large or family shareholders have strong incentives to oversee agents' activities because of being insiders, strong commitment and better firm specific knowledge (Bertrand and Schoar, 2006, Harris and Raviv, 2008, Jensen and Warner, 1988, Su et al., 2010). Therefore, concentrated and family ownership generally suggests that shareholders are better able to protect their interests in their companies, leading to reduced managerial opportunism, higher interest alignment and lower CEO compensation. 
However, entrenchment effect suggests that family or controlling shareholders can expropriate minority shareholders' interests through many ways including excessive compensation packages (see, Croci et al., 2012, Su et al., 2010, Wang and Xiao, 2011). CEOs in close relation with controlling shareholders/family may set their own pay opportunistically high, thereby expropriating the minority shareholders' wealth. Such expropriation is very likely in emerging markets where formal institutions are weak to support mutually beneficial impersonal exchange between economic players (see, Jameson et al., 2014, Young et al., 2008). Since Pakistan is an emerging market with weak legal systems, therefore we hypothesize that:

H2a: Ownership concentration has a positive impact on CEO compensation H2b: CEO compensation is higher in family firms than in non-family firms

\section{Board Size and CEO Compensation}

Board size is considered as an important determinant of board effectiveness. It has significant contribution towards quality of governance (Jensen, 1993, Lipton and Lorsch, 1992). Larger boards are likely to correlate with greater level of expertise and firm's ability to extract critical resources (Dalton et al., 1999, Provan, 1980). However, they may become so heavy, leading to ineffective executive monitoring (Jensen, 1993). Larger boards are less likely to function effectively and are easier to be controlled by executives (Jensen, 1993, Lipton and Lorsch, 1992). In addition, they are likely to be plagued with communication and coordination problem (Ozkan, 2007). Thus, larger boards are assumed to compromise their monitoring role and hence weaken the internal governance structure. Consequently, executives gain more power over the internal control mechanisms, leading to more influence on their own pay, resulting in higher executive compensation. Many studies find that larger boards are related to higher executive compensation 
(e.g., Core et al., 1999, Croci et al., 2012, Fahlenbrach, 2009, Ozkan, 2011, Shah et al., 2009, van Essen et al., 2012b).

In Pakistan, board size generally tends to be driven by directors appointed from the controlling families or by proxy directors working on behalf of controlling shareholders. Consequently, it is less likely that board size has any effective role in reducing agency conflicts. In that case, board size is not expected to influence CEO compensation. Therefore, we hypothesize that:

\section{H3: Board size has no influence on the CEO compensation}

\section{Board Independence and CEO Compensation}

Agency theory suggests that independent directors are likely to play important role in aligning shareholder-manager interests by providing adequate monitoring. Independent outside directors are less subject to collude with management and have reputation to protect shareholders in the labor market (Core et al., 1999, Fama and Jensen, 1983). On the other hand, inside directors are more obligated to $\mathrm{CEO}$ and can be under greater $\mathrm{CEO}$ influence, leading to compromised CEO monitoring to get personal benefits from CEO such as career opportunities (see, Bebchuk and Fried, 2003, Weisbach, 2007). Nevertheless, external directors are also prone to have negative impact on internal governance if they have some secret relationship with management (Core et al., 1999). Overall, board independence is expected to be related to less managerial opportunism, leading to lower executive compensation.

Empirically, available evidence is mixed over the relationship between board independence and executive compensation. For example, Boyd (1994) and Core et al. (1999) find positive association, while others (e.g., Byrd and Cooperman, 2010, Conyon and He, 2011, Conyon and He, 2012) find no or negative relationship between number of independent directors in board and executive compensation. Given the Pakistani context where non-executive directors are generally 
hired from within the family or obligated to work on behalf of controlling shareholders (Javid and Iqbal, 2008, World Bank, 2005), we may expect so-called board independence to become irrelevant in corporate decision making, leading to non-negative relation between CEO pay and board independence. Therefor our hypothesis is:

\section{H4: Board Independence has no impact on CEO compensation}

\section{CEO Duality and CEO Compensation}

CEO duality (CEO as chairman board of directors at the same time) provides opportunities to "self-interested" CEOs to influence major decisions in order to maximize their own utilities instead of maximizing shareholders' wealth (Core et al., 1999, Jensen, 1993). CEO duality reduces the board independence and increases the executive powers over control decisions including designing executive compensation contracts, leading to higher executive compensation. Thus, CEO duality is considered to be a sign of inefficient corporate governance in both agency theory and managerial power theory.

Empirically, most of the studies (e.g., Boyd, 1994, Brick et al., 2006, Conyon and He, 2012, Core et al., 1999, Fahlenbrach, 2009, van Essen et al., 2012b) find positive association between CEO duality and executive compensation, indicating the likelihood of CEO entrenchment and excessive payment to CEO when he/she is also a chairman board of directors. In Pakistan, Code of corporate governance encourages companies to separate CEO position from chairman board of directors. ${ }^{3}$ Thus, CEO duality is considered to be a potential cause of managerial entrenchment in Pakistan. Accordingly, we expect that CEO compensation is higher when CEO also holds the position of chairman board of directors. We formally hypothesize that:

\section{H5: CEO duality has a positive impact on CEO compensation}

\footnotetext{
${ }^{3}$ In the revised version of the Code of corporate governance issued in March 2012, separation of position of chairman from CEO is mandatory with effect from year 2013.
} 


\section{Methodology}

\section{Data}

We focus on all the non-financial firms listed at Karachi Stock Exchange (KSE), Pakistan for the period 2005 to 2012. Out of 399 non-financial listed companies classified in 12 industrial groups by State Bank of Pakistan (SBP), 139 companies are dropped because either they are declared as defaulted by KSE, newly listed or merged/demerged (86 companies), or their data on corporate governance and compensation is not available (53 companies). All the data is extracted from companies' annual reports collected by hand from different sources including SBP, KSE and companies' websites. As we go farther from 2012, the availability of annual reports decreases therefore sample period is restricted to start from 2005.

For the remaining 260 companies, we managed to collect data for at least three consecutive years, making an unbalanced panel data containing 1836 firm-year observations. However, out of 1836 firm-year observations 328 observations are dropped because in those observations, CEOs are not paid any compensation. Final sample contains 1508 firm-year observations from 225 firms for the period 2005 to 2012 .

\section{Static CEO Pay Model}

Following existing literature (e.g., Gallego and Larrain, 2012, Murphy, 1999, Sun et al., 2013, Wang and Xiao, 2011), the following linear model is estimated to test the association of CEO compensation with firm performance and corporate governance in a static pay process:

$$
\begin{aligned}
\text { LNCOMP }_{i t}= & \beta_{1} \text { ROA }_{i t}+\beta_{2} \text { TRET }_{i t}+\beta_{3} \text { OWNCONS }_{i t}+\beta_{4} \text { FAMOWN }_{i t}+\beta_{5} \text { BDSIZE }_{i t} \\
& +\beta_{6} B_{-} I N D_{i t}+\beta_{7} \text { DUALCEO } \\
& +\beta_{10} \text { FIRMSIZE }_{i t}+\beta_{11} \text { FIRMRST }_{i t}+\beta_{12} \text { MTB }_{i t}+\beta_{13} \text { FMAGE }_{i t} \\
& +\beta_{14} \text { CEOCHNG }_{i t}+\alpha_{i}+\omega_{t}+\varepsilon_{i t}
\end{aligned}
$$


Where $\mathrm{LNCOMP}_{\text {it }}$ is log of compensation. In Pakistan, long term incentive plans, stock options and restricted stocks are virtually non-existent. CEOs are paid in the form of base salary, cash bonuses, perks and benefits and post-employment benefits. Companies use many accountings heads in disclosure and nomenclature of the accounting heads is not uniform across the firms. The predominantly used accountings heads include managerial remuneration, bonus, leave encashment, house rent, utilities, medical expenses, gratuity, provident fund and retirement benefits. Consistent with existing literature, we use two measures of CEO compensation i.e., cash compensation and total compensation. Cash compensation includes managerial remuneration and bonuses while total compensation is the sum of all the components. $\mathrm{ROA}_{\mathrm{it}}$, return on assets, represents accounting performance and it is measured as ratio of income before interest and taxes (EBIT) to total assets. TRET $\mathrm{it}_{\mathrm{it}}$, total return to shareholder, represents market performance and it is measured as current market price of shares plus dividend for the current year divided by previous year market price. In Pakistan, it takes about four months until annual reports are published and distributed. Therefore, to avoid any inconsistencies, market price per share is taken on the date that is four months after the closing date.

OWNCONS represents ownership concentration. Consistent with existing literature (see, Holderness, 2014, La Porta et al., 1999), we use ownership of largest shareholder as a proxy for ownership concentration. FAMOWN is a dummy variable taking value 1 for family firms and zero otherwise. Following Anderson and Reeb (2003), Achleitner et al. (2014) and others, we define a family firm that fulfills one of the two conditions, 1) a person or family group hold at least $25 \%$ of voting right as measured by the percentage of shares owned directly or indirectly, 2) two or more family members sit on the board of directors. 
BDSIZE, board size, is measured as number of directors sitting on the board as mentioned in the annual reports. Although Code of corporate governance in Pakistan encourages the representation of independent directors on the board, however, this has not been a mandatory requirement until year 2013. Further, disclosure regarding independent director is very much inconsistent across the companies. Therefore, we use ratio of non-executive directors to board size as a measure of board independence (B_IND). DUALCEO is CEO-duality and it is incorporated as a dummy variable taking the value of one if CEO is also the chairman of the board of directors and zero otherwise.

Institutional ownership and group affiliation are important drivers of corporate governance in emerging markets. According to agency theory, institutional ownership serves a monitoring role and is related to lower CEO compensation (Hartzell and Starks, 2003). Similarly, behavior of business group firms is known to be different from their counterparts (Siegel and Choudhury, 2012). Ghosh (2006), for instance, reports that CEO compensation is lower in group affiliated firms in India which have similar socioeconomic structure like Pakistan's. We therefore, control for institutional ownership and group affiliation. Institutional ownership (INSTOWN) is measured by percentage of shares held by institutions while Group (GROUP) is a dummy variable that takes value 1 if a firm belongs to a group and zero otherwise.

Other control variables include firm size (FIRMSIZE) which is measured as log of total assets, firm risk (FIRMRSK), which is measured as standard deviation of monthly stock returns for the fiscal year, growth opportunities (MTB) proxied by market to book ratio as measured by market value per share divided by book value per share, firm age (FMAGE) as indicated in the annual reports. 
Firm size is perhaps one of the most cited determinants of CEO compensation across the world. Countless studies report that firm size is positively related to executive compensation (e.g., Devers et al., 2007, Frydman and Jenter, 2010). Managing a risky company needs better managerial skills, leading to higher compensations (Brick et al., 2006, Conyon and He, 2011, Core et al., 1999). Firms with greater growth opportunities are expected to hire the executives with better skills who can exploit the available growth opportunities to maximize the shareholder value. This leads to a positive link between growth opportunity and CEO compensation (e.g., Brick et al., 2006, Conyon and He, 2012, Ho et al., 2004). Similarly, aged firms are more likely to devise more efficient compensation contracts (see, e.g.,Conyon and He, 2012, Ho et al., 2004). Finally, if CEO is replaced in a firm, the new contract is unlikely to be the same as the previous one. Further, if CEO is replaced in the middle of a year, there would be two persons drawing compensation in a year. Therefore, to account for such instances, we include a variable (CEOCHNG) that represents how many times a firm changes its CEO during the year, measured as an interaction term of dummy variable taking value 1 if $\mathrm{CEO}$ is replaced during the year and number of CEOs drawing remuneration during the year.

In order to account for unobserved heterogeneity, we estimate fixed effect model after performing Hausman (1978) test. In addition, Both Breusch-Pagan/Cook-Weisberg heteroskedasticity test and White heteroskedasticity test indicate the presence of heteroskedasticity. Similarly, Wooldridge (2002) test for serial correlation in panel data suggests the presence of serial correlation in error terms. Therefore, we use Huber-White robust standard errors clustered at firm level. This adjustment of standard errors accounts for both heteroskedasticity and serial correlation (Greene, 2011). 


\section{CEO Pay Persistence and Dynamic Panel Model}

Agency theory assumes that executive compensation contracts are static pay-for-performance contracts, where CEO compensation is in equilibrium in each period. However, learning is an important factor that affects wage dynamics within a firm (Conyon and He, 2012). When an employee enters the labor market, his/her ability is partially observable by the employer. Education, experience, and other characteristics do reflect initial quality of the employee but still this information is incomplete. Therefore, initial wage decision has to be made by the employer on the basis of employee's expected performance. The employer then gradually learns about capabilities of the employee from his/her subsequent real performance. The employer's information and belief about the employee's performance accumulate and are serially correlated (Conyon and He, 2012). Therefore, wages based on such expectations are expected to correlate in adjacent years. This potential correlation however is ignored in the majority of previous studies on executive compensation (Conyon and He, 2012). Another viewpoint that is relevant to adjacent year correlation in executive compensation is anchoring-and-adjustment heuristic (Bender, 2003, Tversky and Kahneman, 1974). Tversky and Kahneman (1974), for instance, suggest that in many situations people make numerical estimates by starting from an initial value (the anchor), and adjusting this to yield a final answer. However, the adjustments made are usually insufficient therefore different starting points yield different estimates which are biased towards the anchor (Bender, 2003, Raithatha and Komera, 2016). The board of directors/compensation committee often have a figure as a starting point i.e., prior year's compensation which has an influence on the current pay levels (Bender, 2003, Raithatha and Komera, 2016).

As argued above, the current CEO compensation may be a function of previous year's CEO compensation because of incomplete information and dynamic learning process, and anchoring- 
and-adjustment heuristic. Therefore, we also estimate dynamic panel model in addition to static panel model to account for CEO pay persistence and dynamic adjustment.

The estimated model is as follows:

$$
\begin{aligned}
\operatorname{LNCOMP}_{i t}= & \alpha+\gamma \text { LNCOMP }_{i t-1}+\beta_{1} \text { ROA }_{i t}+\beta_{2} \text { TRET }_{i t}+\beta_{3} \text { OWNCONS }_{i t} \\
& +\beta_{4} \text { FAMOWN }_{i t}+\beta_{5} \text { BDSIZE }_{i t}+\beta_{6} \text { B IND }_{i t}+\beta_{7} \text { DUALCEO }_{i t} \\
& +\beta_{8} \text { INSTOWN }_{i t}+\beta_{9} \text { GROUP POU }_{i t}+\beta_{10} \text { FIRMSIZE }_{i t}+\beta_{11} \text { FIRMRSK }_{i t} \\
& +\beta_{12} \text { MTB }_{i t}+\beta_{13} \text { FMAGE }_{i t}+\beta_{14} \text { CEOCHNG }_{i t}+\omega_{t}+\varepsilon_{i t}
\end{aligned}
$$

The definitions of variables are the same as in model (1).

We estimate model (2) using instrumental variable (IV) approach and generalized method of moment (GMM) estimator. This strategy control for potential endogeneity problem in addition to unobserved heterogeneity. Before proceeding, we first test the endogeneity of the regressors using Durbin-Wu-Hausman (DWH) test for endogeneity of all the regressors following Schultz et al. (2010) and Nguyen et al. (2015).

We use system-GMM approach because it is more efficient (Blundell and Bond, 1998, Roodman, 2009). System-GMM reduces the effect of high persistence of corporate governance variables thereby improving the power of estimations (Blundell and Bond, 1998, Nguyen et al., 2015). In addition, system-GMM appears to be the best-performing estimator for the data which is characterized by moderate length of time, low within firm variations in corporate governance variables, possibility of fixed effects driven dependent variable, some variables are endogenous and a dynamic relationship exists between variables (Filatotchev et al., 2013, Nguyen et al., 2015, Zhou et al., 2014). Our data reasonably possess similar properties. The choice of instrumental variables is crucial in GMM estimation techniques. We use Sargan (1958)/Hansen (1982) overidentification tests and Arellano and Bond (1991) autocorrelation test for validity and suitability of the instrumental variables ${ }^{4}$.

\footnotetext{
${ }^{4}$ See Roodman (2009) for details
} 


\section{Empirical Results}

\section{Descriptive Statistics}

Table 1 presents the descriptive statistics. CEO compensation is deflated to the base year 2005 using Consumer Price Index (CPI). During 2005 to 2007 CEO compensation increases first then appears to be decreasing in financial crisis period till 2010. After that again there is an upward trend. Consistently lower median value than mean value indicates that the distribution of compensation is positively skewed suggesting that greater number of CEOs are receiving pay that is less than overall average pays.

Mean Return on Assets (ROA) of pooled sample is 10.99 percent with standard deviation of 13.39 percent while median is $9.51 \%$. Average ROA does not seem to vary abnormally across the years. ROA decreases from $12.52 \%$ in year 2006 to $10.17 \%$ in year 2007 followed by $9.78 \%$ in year 2008 and $9.26 \%$ in year 2009. This is possibly because of three reasons: 1) unrest due to political issues and general elections, 2) start of energy crisis in Pakistan or 3) effects of financial crisis.

Market return, appears to be more fluctuating than ROA. In year 2005 average market return is $27.70 \%$ which dramatically decrease to $3.49 \%$ in year 2006 followed by an increase to $24.87 \%$ in year 2007. Negative returns in year 2008 and 2009 seem to be indicating political unrest, energy crisis and financial crisis. Recovery seems to start after that with positive market returns.

Average board size of pooled sample appears to be slightly above 8 with standard deviation of 1.57. Recently, Jameson et al. (2014) report similar average board size of 8 for Indian firms. This is possibly due to resemblance in institutional setting of concentrated and family ownership structure in India and Pakistan. The average board size in Pakistan is lower than the board size recently reported for China (mean 9.372 and median 9) and US (mean 9.54 and median 9) where 
state has the major stake in the firms or ownership is widely held (see, Conyon, 2014, Huang and Wang, 2015).

Boards are comprised of $63 \%$ non-executive directors on average. However, percentage of non-executive directors has slightly downward trend till 2011, seemingly because of decrease in board size over time. The non-executive directors are more likely to be an easy target when board size needs to be reduced.

About $75 \%$ observations in our sample are from family firms and, quite expectedly, this ratio is almost stable over the sample period. The largest shareholder appears to be holding more than $30 \%$ average voting shares, indicating a highly-concentrated ownership environment. Interestingly, ownership concentration has slightly increasing trend over time which could have implications for CEO compensation contracts.

On average about $34 \%$ CEOs appear to be holding the position of chairman board of directors also. CEO duality shows maximum value i.e., $36 \%$ in 2008, 2009 and 2010, the time characterized by political unrest, energy crisis and financial crisis. However, recent downward trend in 2011 and 2012 seems to be consistent with greater emphasis on separating the position of chairman and CEO in Pakistan. This recent trend is similar to the UK and China where emphasis is on separating the post of CEO from the chairman, and unlike the US where it is usual to combine these two positions (Conyon and He, 2012).

[Table 1 near here]

[Table 2 near here]

\section{Correlation Analysis}

Table 2 presents the correlation matrix. Log transformation is performed for compensation variables and firm size proxy i.e., total assets. Multicollinearity does not seem to be a problem in 
the data as none of the absolute values of correlation coefficients between explanatory variables is greater than 0.70 . This is further confirmed by variance inflation factor (VIF) as none of the VIF is greater than the commonly used threshold level of 10 (unreported).

Both cash and total compensation have positive correlation with accounting performance (ROA) but correlation with market performance (market return) is not significant although sign is positive. Board structure variables board size and board independence are also positively correlated with compensation, indicating potential ineffectiveness of board structure in monitoring and reducing CEO compensation. Family firms seem to pay lower compensation to CEO as depicted by negative correlation between family ownership and both measures of CEO compensation.

Inconsistent with agency theory, ownership concentration is positively correlated with compensation. Similarly, CEO duality is negatively correlated with CEO compensation which is inconsistent with both agency theory and managerial power theory. Firm size, market to book and firm age appear to have positive correlation with compensation. However, CEO compensation is reduced as firm risk increases which is inconsistent with the argument that risky firms need to pay higher compensation to their CEOs.

\section{Estimation Results}

Table 3 presents the estimation results for total compensation and cash compensation as dependent variables. Robust standard errors are reported for pooled and fixed effect models while Wind-Meijer-corrected standard errors are reported for dynamic panel models. Arellano-Bond serial correlation tests $\mathrm{m} 1 \& \mathrm{~m} 2$ and instrument over-identification tests are also reported at the bottom of the table. Arellano-Bond test for second order (m2) validates the use of second and 
earlier lags of dependent variables as instruments. None of the values of $\mathrm{m} 2$ rejects the hypothesis of no second order correlation in error terms. Similarly, p-values of over-identification tests, Sargan test and Hansen $\mathbf{J}$ test, do not lead to rejecting the hypothesis of joint validity of the instruments used.

Consistent with the agency theory, both measures of CEO compensation are positively related to current firm accounting performance as measured by ROA. The results are consistent qualitatively over different model specifications. This confirms that despite CEOs are seemingly more powerful than the boards, their compensation is still linked to firms' accounting performance. This finding seems to be inconsistent with managerial power hypothesis and expropriation view as discussed earlier.

Market returns do not significantly contribute to pay setting process as coefficient of market return is not significantly different from zero in all models. Since CEO compensation in Pakistan rarely includes any restricted stocks, stock options and other stock based bonuses, therefore weak link between CEO compensation and market performance is expected. Another possible reason for an insignificant relationship between CEO compensation and market performance could be that Pakistani bourses are considered to be highly volatile (Sheikh and Riaz, 2012), therefore using market performance as benchmark for setting CEO compensation may not be a good choice.

[Table 3 near here]

We also find positive pay-performance link for past accounting performance when we replace current firm performance variables with their lagged values in the models (unreported). However, surprisingly, lagged market performance appears to have negative association with both measures of CEO compensation. This negative association may be interpreted as sign of cronyism which 
predict negative association between excessive pay and firm performance (Brick et al., 2006). However, we believe that this negative association is more probably due to highly volatile bourses in Pakistan. During the periods of bad market performance, especially from 2008 to 2011, the compensation may have increased due to positive accounting performance, leading to negative relationship between current compensation and previous year market performance.

Consistent with pay persistence and dynamic adjustment arguments as discussed above, the coefficients of lagged CEO pay in dynamic panel models are positive and significant, indicating that CEO pay is highly persistent and takes time to adjust to its long-term equilibrium level. The boards consider previous year CEO compensation as a reference point while setting next year compensation. This is an important finding of this study as most of the literature on CEO compensation ignores the dynamic nature of CEO compensation and estimate static pay models considering that pay is in equilibrium.

Ownership concentration appears to have positive impact on both measures of CEO compensation which is consistent with our hypothesis. The coefficients of ownership concentration are significantly positive. This is consistent with expropriation view which leads to support hypothesis $2 \mathrm{a}$. Controlling shareholders might be engaged in colluding with management to get personal benefits at the expense of minority shareholders thus overlooking level of CEO compensation.

In pooled regression, CEOs seem to receive lower compensation in family firms. However, in fixed effect and dynamic panel model, the coefficients of family ownership do not appear to be significant. Thus, we find weak evidence that family ownership significantly influence the CEO pay setting process. The inconsistencies in results across different models need to be explored further using more variables on family characteristics as discussed by Bertrand and Schoar (2006). 
Inconsistent with many studies (e.g., Core et al., 1999, Croci et al., 2012, Fahlenbrach, 2009, Ozkan, 2011, Shah et al., 2009, van Essen et al., 2012b), the coefficient of board size is consistently insignificant in all models which suggests that board size does not matter. Similarly, the coefficient of board independence is insignificant in all models, indicating no influence of non-executive directors on CEO pay process. These results are consistent with the general view that boards in Pakistan are dominated by non-executive directors who are hired from within the family or they have close relation with controlling shareholders (Javid and Iqbal, 2008). These are gray directors who do not have real influence on decisions made by family/controlling shareholders. The number of such directors does not matter hence the board size does not matter. Thus, our hypotheses 3 and 4 are supported.

Surprisingly, in contrast to many existing studies (e.g., Boyd, 1994, Brick et al., 2006, Conyon and He, 2012, Core et al., 1999, Fahlenbrach, 2009, van Essen et al., 2012b), CEO duality appears to be significantly negatively related to both measures of CEO compensation. The coefficients of CEO duality are consistently negative in all model specifications. Thus, the argument that more concentrated power in one person by combining the position of CEO and chairman board of directors leads to expropriation through higher CEO compensation is not supported in Pakistan.

Group affiliation is not creating any significant difference in level of CEO compensation as indicated by insignificant coefficients. However, institutional holding does have significant positive influence on CEO compensation. This questions the monitoring role of institutional ownership as suggested by the agency theory (see, Hartzell and Starks, 2003).

Firm size as measured by log of total assets appears to be significantly positively related to both measures of CEO compensation in all models. This supports the argument that larger firms are complex and difficult to run and hence require quality CEOs with higher compensations. As 
expected, firm age is positively associated with CEO compensation, while newly appointed CEOs are more likely to start with lower compensation than the leaving CEOs as suggested by some significant negative coefficients of CEO changed. Other control variables, firm risk and market to book, do not appear to influence CEO compensation decisions.

\section{Robustness Checks}

Although results presented are robust across different model specifications however, we carry out some further tests of robustness of our results. First, all the continuous variables are winsorized using $1 \%$ level at both tails to eliminate potential outliers and all models are re-estimated. But, the results do not change qualitatively therefore it is decided to report the original data results. Second, alternative measures of firm accounting performance, firm size and ownership concentration, such as, log of net sales, earnings per share (EPS) and voting shares held by three largest shareholders respectively, are incorporated. Again, the results remain qualitatively similar to as reported above. Third, to control for endogeneity problem, following a number of studies (e.g., Croci et al., 2012, Ozkan, 2011) current values of all independent variables except firm age and change of CEO in Model (1) are replaced with their lagged values treating them as potential cause of endogeneity. However, again, results remain largely unaltered. We also estimate models by incorporating group, family ownership, ownership concentration, institutional ownership individually but results remain largely the same as reported. Since correlation between these variables and variance inflation factor are within acceptable range therefore we decided to report them in one model.

\section{Conclusions}

In Pakistan, investor protection and legal systems are weak. Therefore, firms' ownership is concentrated in few individuals or families, leading to more agency problems between controlling 
and minority shareholders. Further, Code of corporate governance issued to improve corporate governance practices in Pakistan has much emphasis on the board structure. Given the Pakistani context, we study how firm performance, concentrated/family ownership and board structure contribute towards CEO pay setting process.

Using different model specifications including a dynamic panel model that also account for dynamic adjustment of dependent variable and control for endogeneity problem, we find that current and previous year firm accounting performance has significant positive influence on CEO compensation. However, firm current market performance does not have any influence on CEO compensation but surprisingly previous year's market performance seems to be negatively influencing the CEO compensation. We believe that this negative association is mainly driven by highly volatile markets in Pakistan which are preventing boards to base CEO compensation on market performance.

An important finding of this study is that CEO pay is highly persistent and takes time to adjust to long-run equilibrium. Thus, current CEO compensation also depends upon their previous year compensation and their innate time-invariant capabilities which are not fully observable initially but gradually in subsequent periods through their real outputs. Further, the boards use previous year CEO compensation as starting point to set next year compensation.

Inconsistent with agency theory, we find that ownership concentration has positive impact on CEO compensation. This finding supports the rent extraction view. There may be some sort of collusions between management and largest shareholder for rent extraction. In addition, we find weak evidence that CEOs in family firms receive lower compensation than their counterparts. Thus, overall, ownership structure does not affect CEO compensation as suggested by agency theory. 
Board structure variables, board size and board independence, have no convincing influence on CEO compensation in any direction, indicating that board size and the number of non-executive directors do not matter when CEO compensation is set. Although agency theory suggest that CEO duality leads to higher CEO compensation, however we find that CEO duality actually leads to lower CEO compensation in Pakistan.

Overall, our findings suggest that firms' accounting performance is an important determinant of CEO compensation. However, ownership concentration and board structure variables are not affecting CEO compensation in the way suggested by agency theory. Therefore, in order to understand CEO pay puzzle and corporate governance in emerging markets, future research needs to account for differences in institutional context of the market under examination. 


\section{References}

Achleitner, A.-K., Günther, N., Kaserer, C. \& Sicilianb, G. 2014. Real Earnings Management and Accrual based Earnings Management in Family Firms. European Accounting Review, 23, 431-461.

Anderson, R. C. \& Reeb, D. M. 2003. Founding family ownership and firm performance: Evidence from the S\&P 500. Journal of Finance, 58, 1301-1329.

Arellano, M. \& Bond, S. 1991. Some Tests of Specification For Panel Data: Monte Carlo Evidence and an Application to Employment Equations. Review of Economic Studies, 58, 277-297.

Basu, S., Hwang, L.-S., Mitsudome, T. \& Weintrop, J. 2007. Corporate governance, top executive compensation and firm performance in Japan. Pacific-Basin Finance Journal, 15, 56-79.

Bayless, M. 2009. The myth of executive compensation: do shareholders get what they pay for? Applied Financial Economics, 19, 795-808.

Bebchuk, L. A. \& Fried, J. A. 2003. Executive compensation as an agency problem. Journal of Economic Perspectives, 17, 71-92.

Bender, R. 2003. How executive directors' remuneration is determined in two FTSE 350 utilities. Corporate Governance, 11, 206-217.

Bertrand, M. \& Schoar, A. 2006. The Role of Family in Family Firms. Journal of Economic Perspectives, 20, 73-96.

Blundell, R. \& Bond, S. 1998. Initial Conditions and Moment Restrictions in Dynamic Panel Data Modeis. Journal of Econometrics, 87, 115-143.

Boyd, B. K. 1994. Board Control and Ceo Compensation. Strategic Management Journal, 15, 335-344.

Brick, I. E., Palmon, O. \& Wald, J. K. 2006. CEO compensation, director compensation, and firm performance: Evidence of cronyism? Journal of Corporate Finance, 12, 403-423.

Bryson, A., Forth, J. \& Zhou, M. 2014. Same or different? The CEO labour market in China's publicly listed companies. Economic Journal, 124, 90-108.

Buck, T., Liu, X. \& Skovoroda, R. 2008. Top Executive Pay and Firm Performance in China. Journal of International Business Studies, 39, 833-850.

Byrd, J. \& Cooperman, E. 2010. Director Tenure and the Compensation of Bank CEOs. Managerial Finance, 36, 86-102.

Conyon, M. J. 2014. Executive Compensation and Board Governance in US Firms. The Economic Journal, 124, F60-F89.

Conyon, M. J. \& He, L. 2011. Executive compensation and corporate governance in China. Journal of Corporate Finance, 17, 1158-1175.

Conyon, M. J. \& He, L. 2012. CEO Compensation and Corporate Governance in China. Corporate Governance: An International Review, 20, 575-592.

Core, J. E., Holthausen, R. W. \& Larcker, D. F. 1999. Corporate governance, chief executive officer compensation, and firm performance. Journal of Financial Economics, 51, 371-406.

Croci, E., Gonenc, H. \& Ozkan, N. 2012. CEO compensation, family control, and institutional investors in Continental Europe. Journal of Banking \& Finance, 36, 3318-3335.

Dalton, D. R., Daily, C. M., Johnson, J. L. \& Ellstrand, A. E. 1999. Number of Directors and Financial Performance: A Meta-Analysis. The Academy of Management Journal, 42, 674-686.

Devers, C. E., Cannella, A. A., Reilly, G. P. \& Yoder, M. E. 2007. Executive compensation: A multidisciplinary review of recent developments. Journal of Management, 33, 1016-1072.

Durnev, A. \& Kim, E. H. 2005. To steal or not to steal: firm attributes, legal environment, and valuation. Journal of Finance, 60, 1461-1493.

Fahlenbrach, R. 2009. Shareholder Rights, Boards, and CEO Compensation. Review of Finance, 13, 81113.

Fama, E. F. \& Jensen, M. C. 1983. Separation of ownership and control. Journal of Law \& Economics, 26, 301-325. 
Fan, J. P. H., Wei, K. C. J. \& Xu, X. 2011. Corporate finance and governance in emerging markets: A selective review and an agenda for future research. Journal of Corporate Finance, 17, 207-214.

Filatotchev, I., Jackson, G. \& Nakajima, C. 2013. Corporate governance and national institutions: A review and emerging research agenda. Asia Pacific Journal of Management, 30, 965-986.

Frydman, C. \& Jenter, D. 2010. CEO Compensation. Annual Review of Financial Economics, 2, 75-102.

Gallego, F. \& Larrain, B. 2012. CEO compensation and large shareholders: Evidence from emerging markets. Journal of Comparative Economics, 40, 621-642.

Ghosh, A. 2006. Determination of Executive Compensation in an Emerging Economy: Evidence from India. Emerging Markets Finance and Trade, 42, 66-90.

Gibson, M. S. 2003. Is Corporate governance ineffective in emerging markets? Journal of Financial and Quantitative Analysis, 38, 231-250.

Greene, W. H. 2011. Econometric Analysis, Pearson Education.

Hansen, L. P. 1982. Large sample properties of generalized method of moments estimators. Econometrica, 50, 1029-1054.

Harris, M. \& Raviv, A. 2008. A theory of board control and size. Review of Financial Studies, 21, 17971832.

Hartzell, J. C. \& Starks, L. T. 2003. Institutional Investors and Executive Compensation. Journal of Finance, 58, 2351-2374.

Hausman, J. 1978. Specification Tests in Econometrics. Econometrics, 46, 1251-1273.

Ho, S. S. M., Lam, K. C. K. \& Sami, H. 2004. The investment opportunity set, director ownership, and corporate policies: Evidence from an emerging market. Journal of Corporate Finance, 10, 383-408.

Hofstede, G. H. 1980. Culture's consequences: International differences in work-related values, Beverly Hills, CA, Sage.

Holderness, C. G. 2014. Culture and the ownership concentration of public corporations around the world. Journal of Corporate Finance, Article in Press.

Huang, Y. S. \& Wang, C.-J. 2015. Corporate governance and risk-taking of Chinese firms: The role of board size. International Review of Economics and Finance, 37, 96-113.

Jameson, M., Prevost, A. \& Puthenpurackal, J. 2014. Controlling shareholders, Board Structure, and Firm Performance: Evidence from India. Journal of Corporate Finance, 27, 1-20.

Javid, A. Y. \& Iqbal, R. 2008. Ownership Concentration, Corporate Governance and Firm Performance: Evidence from Pakistan. The Pakistan Development Review, 47, 643-659.

Jensen, M. 1993. The modern industrial revolution. Exit, and the failure of internal control systems. Journal of Finance, 48, 831-880.

Jensen, M. \& Meckling, W. 1976. Theory of the firm: Managerial behavior, agency costs, and ownership structure. Journal of Financial Economics, 3, 305-360.

Jensen, M. C. \& Warner, J. B. 1988. The distribution of power among corporate managers, shareholders, and directors. Journal of Financial Economics, 20, 3-24.

Kamran \& Shah, A. 2014. The Impact of Corporate Governance and Ownership Structure on Earnings Management Practices: Evidence from Listed Companies in Pakistan. The Lahore Journal of Economics, 19, 27-70.

Kashif, S. \& Mustafa, K. 2012. The Determinants of CEO Compensation: Evidence from Family-Owned Listed Corporations in Karachi Stock Exchange. Middle East Journal of Economics and Finance, $5,45-61$.

Kato, T., Kim, W. \& Lee, J. H. 2007. Executive compensation, firm performance, and Chaebols in Korea: Evidence from new panel data. Pacific-Basin Finance Journal, 15, 36-55.

Klapper, L. F. \& Love, I. 2003. Corporate governance, investor protection, and performance in emerging markets. Journal of Corporate Finance, 10, 703-728.

La Porta, R., Lopez-De-Silanes, F. \& Shleifer, A. 1999. Corporate Ownership Around the World. The Journal of Finance, 54, 471-517.

Lipton, M. \& Lorsch, J. W. 1992. A modest proposal for improved corporate governance. Business Lawyer, 48, 59-77. 
Mujtaba, B. G. \& Afza, T. 2011. Business Ethics Perceptions of Public and Private Sector Respondents in Pakistan. Far East Journal of Psychology and Business, 3, 1-11.

Murphy, K. J. 1999. Executive compensation. In: ASHENFELTER, O. \& CARDS, D. (eds.) Handbook of Labor Economics. New York: North Holland.

Nguyen, T., Locke, S. \& Reddy, K. 2015. Ownership concentration and corporate performance from a dynamic perspective: Does national governance quality matter? International Review of Financial Analysis, 41, 148-161.

Ozkan, N. 2007. Do corporate governance mechanisms influence CEO compensation? An empirical investigation of UK companies. Journal of Multinational Financial Management, 17, 349-364.

Ozkan, N. 2011. CEO Compensation and Firm Performance: an Empirical Investigation of UK Panel Data. European Financial Management, 17, 260-285.

Provan, K. G. 1980. Board power and organizational effeictiveness among human service agencies. Academy of Management Journal, 23, 221-236.

Raithatha, M. \& Komera, S. 2016. Executive compensation and firm performance: Evidence from Indian firms. IIMB Management Review, 28, 160-169.

Rehman, R., Hasan, M., Mangla, I. \& Sultana, N. 2012. Economic Reforms, Corporate Governance and Dividend Policy in Sectoral Economic Growth in Pakistan. The Pakistan Development Review, 51, 133-146.

Roodman, D. 2009. How to do xtabond2: An introduction to difference and system GMM in Stata. The Stata Journal, 9, 86-136.

Sargan, J. D. 1958. The estimation of economic relationships using instrumental variables. Econometrica, 26, 393-415.

Schultz, E. L., Tan, D. T. \& Walsh, K. D. 2010. Endogeneity and the corporate governance-performance relation. Australian Journal of Management, 35, 145-163.

SECP 2002. Code of Corporate Governance.

SECP 2012. Code of Corporate Governance.

Shah, S. Z. A., Javed, T. \& Abbas, M. 2009. Determinants of CEO Compensation Empirical Evidence from Pakistani Listed Companies. International Research Journal of Finance and Economics, 32, 148-159.

Sheikh, M. F. \& Riaz, K. 2012. Overconfidence Bias, Trading Volume and Returns Volatility: Evidence from Pakistan. World Applied Science Journal, 18, 1737-1748.

Siegel, J. \& Choudhury, P. 2012. A Reexamination of Tunneling and Business Groups: New Data and New Methods. The Review of Financial Studies, 25, 1763-1798.

$\mathrm{Su}, \mathrm{Z}$., Li, Y. \& Li, L. 2010. Ownership concentration and executive compensation in emerging economies: evidence from China. Corporate Governance: An International Review, 10, 223-233.

Sun, F., Wei, X. \& Huang, X. 2013. CEO compensation and firm performance Evidence from the US property and liability insurance industry. Review of Accounting and Finance, 12, 252-267.

Sun, S. L., Zhao, X. \& Yang, H. 2010. Executive compensation in Asia: A critical review and outlook. Asia Pacific Journal of Management, 27, 775-802.

Tosi, H. L., Werner, S., Katz, J. P. \& Gomez-Mejia, L. R. 2000. How Much Does Performance Matter? A Meta-Analysis of CEO Pay Studies. Journal of Management, 26, 301-339.

Tversky, A. \& Kahneman, D. 1974. Judgement Under Uncertainty: Heuristics and Biases. Science, 185, 1124-1131.

van Essen, M., Heugens, P. P. M. A. R., Otten, J. \& Van Oosterhout, J. 2012a. An institution-based view of executive compensation: A multilevel meta-analytic test. Journal of International Business Studies, 43, 396-423.

van Essen, M., Otten, J. \& Carberry, E. J. 2012b. Assessing Managerial Power Theory: A Meta-Analytic Approach to Understanding the Determinants of CEO Compensation. Journal of management, 41, 164-202.

Wang, K. \& Xiao, X. 2011. Controlling shareholders' tunneling and executive compensation: Evidence from China. Journal of Accounting and Public Policy, 30, 89-100. 
Weisbach, M. S. 2007. Optimal executive compensation versus managerial power: A review of Lucian Bebchuk and Jesse Fried's pay without performance: the unfufilled promise of executive compensation. Journal of Economic Literature, 45, 419-428.

Wooldridge, J. M. 2002. Econometric Analysis of Cross Section and Panel Data, Cambridge, MA., MIT Press.

World Bank 2005. Pakistan : Report on the Observance of Standards and Codes (ROSC) : Corporate Governance Country Assessment.

Young, M. N., Peng, M. W., Ahlstrom, D., Bruton, G. D. \& Jiang, Y. 2008. Corporate Governance in Emerging Economies: A Review of the Principal-Principal Perspective. Journal of Management Studies, 45, 196-220.

Zhou, Q., Faff, R. \& Alpert, K. 2014. Bias correction in the estimation of dynamic panel models in corporate finance. Journal of Corporate Finance, 25, 494-513. 
Table 1

Descriptive Statistics

\begin{tabular}{|c|c|c|c|c|c|c|c|c|c|c|}
\hline Variables & Statistic & 2005 & 2006 & 2007 & 2008 & 2009 & 2010 & 2011 & 2012 & Pooled \\
\hline Cash Pay & Mean & 3353 & 3631 & 4092 & 3958 & 3784 & 3639 & 3720 & 4227 & 3810 \\
\hline Rs. in '000' & Median & 2000 & 2134 & 2338 & 2031 & 2165 & 1909 & 1979 & 2338 & 2104 \\
\hline Base 2005 & S.D & 4626 & 5412 & 6706 & 6636 & 5588 & 5362 & 5173 & 6656 & 5819 \\
\hline Total Pay & Mean & 4817 & 5125 & 5609 & 5414 & 5292 & 5229 & 5255 & 5887 & 5341 \\
\hline Rs. in ' 000 ' & Median & 3156 & 3136 & 3577 & 3260 & 3151 & 3021 & 2997 & 3389 & 3210 \\
\hline Base 2005 & S.D & 5854 & 6515 & 7833 & 7896 & 7108 & 6927 & 6672 & 8986 & 7306 \\
\hline \multirow{3}{*}{$\begin{array}{l}\text { Return on } \\
\text { Assets \% }\end{array}$} & Mean & 11.93 & 12.52 & 10.17 & 9.78 & 9.26 & 12.28 & 11.74 & 10.54 & 10.99 \\
\hline & Median & 9.14 & 9.58 & 7.86 & 7.96 & 9.53 & 11.20 & 10.84 & 10.32 & 9.51 \\
\hline & S.D & 11.07 & 10.67 & 11.23 & 11.52 & 19.31 & 11.73 & 12.96 & 14.80 & 13.39 \\
\hline \multirow{3}{*}{$\begin{array}{l}\text { Market } \\
\text { Return \% }\end{array}$} & Mean & 27.70 & 3.49 & 24.87 & -14.35 & -1.73 & 8.37 & -0.47 & 86.46 & 16.74 \\
\hline & Median & 18.97 & -1.01 & 7.38 & -27.20 & -18.04 & & & 47.84 & -0.84 \\
\hline & S.D & 52.18 & 39.08 & 71.94 & 80.74 & 67.19 & 62.89 & 72.12 & 114.89 & 80.04 \\
\hline \multirow{3}{*}{$\begin{array}{l}\text { Ownership } \\
\text { Concentration } \\
\%\end{array}$} & Mean & 32.72 & 33.01 & 33.07 & 33.23 & 33.36 & 33.61 & 34.39 & 35.51 & 33.67 \\
\hline & Median & 26.46 & 26.61 & 26.71 & 26.25 & 26.13 & 26.13 & 27.45 & 29.40 & 26.66 \\
\hline & S.D & 21.01 & 21.22 & 20.78 & 20.48 & 20.44 & 20.30 & 20.74 & 21.32 & 20.74 \\
\hline \multirow{3}{*}{$\begin{array}{l}\text { Family } \\
\text { Ownership }\end{array}$} & & & & & & & & & 0.74 & 0.75 \\
\hline & Median & 1.00 & 1.00 & 1.00 & 1.00 & 1.00 & 1.00 & 1.00 & 1.00 & 1.00 \\
\hline & S.D & 0.44 & 0.43 & 0.43 & 0.43 & 0.44 & 0.43 & 0.43 & 0.44 & 0.43 \\
\hline \multirow{3}{*}{$\begin{array}{l}\text { Board } \\
\text { Size }\end{array}$} & Mear & 8.13 & 8.15 & 8.08 & 8.04 & 8.01 & 8.00 & 8.01 & 8.00 & 8.05 \\
\hline & Median & 7.00 & 7.00 & 7.00 & 7.00 & & 7.00 & & 7.00 & 7.00 \\
\hline & $\mathrm{S}$ & & & & & & & & 1.51 & 1.57 \\
\hline \multirow{3}{*}{$\begin{array}{l}\text { Board } \\
\text { Independence } \\
\%\end{array}$} & Mear & 64.32 & 64.31 & 63.90 & 63.65 & 62.85 & 63.23 & 62.58 & 63.91 & 63.54 \\
\hline & Medi & 70.00 & 70.71 & 70.00 & 66.67 & 66.67 & 66.67 & 62.50 & 66.67 & 66.67 \\
\hline & S.D & 20.37 & 20.72 & 20.71 & 20.59 & 20.94 & 20.64 & 20.31 & 19.96 & 20.49 \\
\hline \multirow[t]{3}{*}{ CEO Duality } & & & & & & & & & 0.33 & 0.34 \\
\hline & $\mathrm{M}$ & 0.00 & 0.00 & 0.00 & 0.00 & 0.00 & 0.00 & 0.00 & 0.00 & 0.00 \\
\hline & S.D & 0.46 & 0.47 & 0.47 & 0.48 & 0.48 & 0.48 & 0.48 & 0.47 & 0.47 \\
\hline \multirow{3}{*}{$\begin{array}{l}\text { Institutional } \\
\text { Ownership } \\
\%\end{array}$} & Mear & 13.93 & 13.48 & 13.10 & 13.92 & 13.22 & 12.21 & 11.60 & 10.65 & 13.22 \\
\hline & Medi & 10.82 & 9.90 & 10.06 & 11.31 & 10.00 & 10.14 & 8.75 & 7.34 & 10.00 \\
\hline & S.D & 12.52 & 11.91 & 10.78 & 11.71 & 11.19 & 10.39 & 10.50 & 9.93 & 11.19 \\
\hline \multirow[t]{3}{*}{ Group Firm } & Mear & 0.63 & 0.63 & 0.63 & 0.62 & 0.60 & 0.59 & 0.60 & 0.62 & 0.61 \\
\hline & $\mathrm{N}$ & 1.00 & 1.00 & 1.00 & 1.00 & 1.00 & 1.00 & 1.00 & 1.00 & 1.00 \\
\hline & & 0.49 & 0.49 & 0.49 & 0.49 & 0.49 & 0.49 & 0.49 & 0.49 & 0.49 \\
\hline \multirow{3}{*}{$\begin{array}{l}\text { Total Assets } \\
\text { Rs in } \\
\text { Millions }\end{array}$} & Mean & 7173 & 8607 & 9827 & 10898 & 11636 & 12675 & 14490 & 17215 & 11833 \\
\hline & Median & 2385 & 2603 & 2970 & 3042 & 3034 & 3068 & 3544 & 3831 & 3061 \\
\hline & S.D & 14281 & 16821 & 18677 & 22158 & 26033 & 31098 & 35893 & 45860 & 29092 \\
\hline \multirow[t]{3}{*}{ Firm Risk \% } & Mea & 15.03 & 12.15 & 12.70 & 13.24 & 24.29 & 17.88 & 14.07 & 15.97 & 15.88 \\
\hline & Medi & 13.54 & 11.20 & 12.13 & 11.66 & 19.32 & 13.18 & 11.15 & 13.29 & 13.01 \\
\hline & S.D & 8.00 & 8.51 & 6.63 & 7.74 & 23.59 & 15.63 & 11.00 & 11.37 & 13.59 \\
\hline \multirow{3}{*}{$\begin{array}{l}\text { Market to } \\
\text { Book }\end{array}$} & Mean & 1.79 & 2.35 & 2.17 & 1.74 & 1.56 & 1.31 & 1.30 & 1.84 & 1.73 \\
\hline & Media & 1.19 & 0.99 & 1.13 & 0.86 & 0.62 & 0.52 & 0.43 & 0.65 & 0.75 \\
\hline & S.D & 2.37 & 8.17 & 4.76 & 4.77 & 4.81 & 6.03 & 4.58 & 5.62 & 5.35 \\
\hline \multirow{3}{*}{$\begin{array}{l}\text { Firm Age } \\
\text { Years }\end{array}$} & Mean & 31.03 & 31.84 & 32.56 & 32.87 & 34.01 & 35.06 & 36.14 & 37.50 & 34.06 \\
\hline & Media & 27.00 & 28.00 & 29.00 & 29.00 & 30.00 & 31.00 & 32.00 & 33.00 & 30.00 \\
\hline & S.D & 16.65 & 16.75 & 16.48 & 16.43 & 16.61 & 16.56 & 16.46 & 16.59 & 16.65 \\
\hline
\end{tabular}


Table 2

Correlation Matrix

\begin{tabular}{|c|c|c|c|c|c|c|c|c|c|c|c|c|c|c|c|c|}
\hline \multicolumn{17}{|c|}{ Correlation Matrix } \\
\hline & & (1) & (2) & (3) & (4) & (5) & (6) & $(7)$ & $(8)$ & (9) & (10) & (11) & (12) & (13) & (14) & (15) \\
\hline Total Compensation & (1) & 1.00 & & & & & & & & & & & & & & \\
\hline Cash Compensation & (2) & $0.97 *$ & 1.00 & & & & & & & & & & & & & \\
\hline Return on Assets & (3) & $0.31^{*}$ & $0.31^{*}$ & 1.00 & & & & & & & & & & & & \\
\hline Market Return & (4) & 0.02 & 0.02 & $0.17^{*}$ & 1.00 & & & & & & & & & & & \\
\hline $\begin{array}{l}\text { Ownership } \\
\text { Concentration }\end{array}$ & (5) & $0.36^{*}$ & $0.37^{*}$ & $0.22 *$ & 0.05 & 1.00 & & & & & & & & & & \\
\hline Family Ownership & (6) & $-0.38^{*}$ & $-0.38^{*}$ & $-0.22 *$ & 0.02 & $-0.54^{*}$ & 1.00 & & & & & & & & & \\
\hline Board Size & (7) & $0.32^{*}$ & $0.31^{*}$ & $0.13^{*}$ & -0.00 & $0.10^{*}$ & $-0.45 *$ & 1.00 & & & & & & & & \\
\hline Board Independence & (8) & $0.19 *$ & $0.14^{*}$ & 0.03 & -0.02 & $0.06^{*}$ & $-0.23 *$ & $0.35^{*}$ & 1.00 & & & & & & & \\
\hline CEO Duality & (9) & $-0.29 *$ & $-0.28^{*}$ & $-0.17 *$ & 0.01 & $-0.08^{*}$ & $0.17^{*}$ & $-0.26^{*}$ & $-0.19 *$ & 1.00 & & & & & & \\
\hline $\begin{array}{l}\text { Institutional } \\
\text { Ownership }\end{array}$ & $(10)$ & $0.15^{*}$ & $0.12^{*}$ & -0.04 & $-0.06 *$ & $-0.15^{*}$ & 0.00 & $0.14^{*}$ & $0.16^{*}$ & $-0.06 *$ & 1.00 & & & & & \\
\hline Group Firm & (11) & $0.08^{*}$ & $0.06^{*}$ & $0.08^{*}$ & 0.00 & $-0.17^{*}$ & $0.28^{*}$ & $-0.06 *$ & 0.04 & $-0.16^{*}$ & $0.07^{*}$ & 1.00 & & & & \\
\hline Firm Size & (12) & $0.58^{*}$ & $0.56^{*}$ & $0.17^{*}$ & -0.04 & $0.25 *$ & $-0.28 *$ & $0.38^{*}$ & $0.13^{*}$ & $-0.22 *$ & -0.00 & $0.06^{*}$ & 1.00 & & & \\
\hline Firm Risk & (13) & $-0.20 *$ & $-0.20 *$ & $-0.19^{*}$ & $0.20 *$ & -0.04 & $0.12^{*}$ & $-0.13^{*}$ & $-0.07^{*}$ & $0.20^{*}$ & 0.00 & $-0.10^{*}$ & $-0.24^{*}$ & 1.00 & & \\
\hline Market to Book & (14) & $0.09 *$ & $0.12^{*}$ & $0.18^{*}$ & $0.07^{*}$ & $0.28 *$ & $-0.17^{*}$ & $0.08^{*}$ & $-0.12 *$ & $-0.10^{*}$ & $-0.13^{*}$ & 0.04 & $0.08^{*}$ & $-0.09 *$ & 1.00 & \\
\hline Firm Age & $(15)$ & $0.25^{*}$ & $0.24 *$ & $0.07^{*}$ & 0.04 & $0.20 *$ & $-0.22^{*}$ & $0.19 *$ & $0.05^{*}$ & -0.02 & $0.07^{*}$ & 0.01 & $0.12^{*}$ & -0.03 & 0.04 & 1.00 \\
\hline
\end{tabular}




\section{Table 3}

\section{CEO Compensation and Firm Performance}

\begin{tabular}{|c|c|c|c|c|c|c|}
\hline \multirow[b]{2}{*}{ VARIABLES } & \multicolumn{3}{|c|}{ Log of Total Compensation } & \multicolumn{3}{|c|}{ Log of Cash Compensation } \\
\hline & $\begin{array}{c}(1) \\
\text { Pooled }\end{array}$ & $\begin{array}{c}(2) \\
\text { Fixed Effects }\end{array}$ & $\begin{array}{c}(3) \\
\text { Dynamic } \\
\text { Panel } \\
(\mathrm{GMM}) \\
\end{array}$ & $\begin{array}{c}(4) \\
\text { Pooled }\end{array}$ & $\begin{array}{c}(5) \\
\text { Fixed Effects }\end{array}$ & $\begin{array}{c}\text { (6) } \\
\text { Dynamic } \\
\text { Panel } \\
(\mathrm{GMM}) \\
\end{array}$ \\
\hline Lagged Compensation & ---- & ---- & $\begin{array}{c}0.7989 * * * \\
(0.0582)\end{array}$ & ---- & ---- & $\begin{array}{c}0.8921 * * * \\
(0.0524)\end{array}$ \\
\hline Return on Assets & $\begin{array}{c}1.2984 * * * \\
(0.3746)\end{array}$ & $\begin{array}{c}1.3044 * * * \\
(0.3412)\end{array}$ & $\begin{array}{c}0.5618 * * * \\
(0.1581)\end{array}$ & $\begin{array}{c}1.3316 * * * \\
(0.3936)\end{array}$ & $\begin{array}{c}1.3326 * * * \\
(0.3651)\end{array}$ & $\begin{array}{c}0.5025 * * * \\
(0.1660)\end{array}$ \\
\hline Market Return & $\begin{array}{c}0.0258 \\
(0.0267)\end{array}$ & $\begin{array}{l}-0.0323 \\
(0.0247)\end{array}$ & $\begin{array}{l}-0.0592 \\
(0.0631)\end{array}$ & $\begin{array}{c}0.0362 \\
(0.0273)\end{array}$ & $\begin{array}{l}-0.0225 \\
(0.0260)\end{array}$ & $\begin{array}{l}-0.0622 \\
(0.0749)\end{array}$ \\
\hline Ownership Concentration & $\begin{array}{c}0.9356^{* * * *} \\
(0.3214)\end{array}$ & $\begin{array}{c}0.7369 * * \\
(0.2917)\end{array}$ & $\begin{array}{l}0.1707 * \\
(0.0937)\end{array}$ & $\begin{array}{c}1.0373 * * * \\
(0.3340)\end{array}$ & $\begin{array}{c}0.8581 * * * \\
(0.3118)\end{array}$ & $\begin{array}{c}0.0676 \\
(0.0954)\end{array}$ \\
\hline Family Ownership & $\begin{array}{c}-0.3407 * * \\
(0.1568)\end{array}$ & $\begin{array}{l}-0.0552 \\
(0.1577)\end{array}$ & $\begin{array}{l}-0.0490 \\
(0.0441)\end{array}$ & $\begin{array}{c}-0.3363^{*} \\
(0.1781)\end{array}$ & $\begin{array}{l}-0.0918 \\
(0.1760)\end{array}$ & $\begin{array}{l}-0.0331 \\
(0.0457)\end{array}$ \\
\hline Board Size & $\begin{array}{l}-0.0082 \\
(0.0408)\end{array}$ & $\begin{array}{l}-0.0081 \\
(0.0379)\end{array}$ & $\begin{array}{c}0.0066 \\
(0.0097)\end{array}$ & $\begin{array}{c}0.0060 \\
(0.0469)\end{array}$ & $\begin{array}{c}0.0141 \\
(0.0431)\end{array}$ & $\begin{array}{c}0.0101 \\
(0.0112)\end{array}$ \\
\hline Board Independence & $\begin{array}{c}0.2134 \\
(0.2788)\end{array}$ & $\begin{array}{c}0.1669 \\
(0.2556)\end{array}$ & $\begin{array}{c}0.0193 \\
(0.0723)\end{array}$ & $\begin{array}{l}-0.0128 \\
(0.2934)\end{array}$ & $\begin{array}{l}-0.0372 \\
(0.2763)\end{array}$ & $\begin{array}{c}0.0445 \\
(0.0648)\end{array}$ \\
\hline CEO Duality & $\begin{array}{c}-0.2955 * * \\
(0.1153)\end{array}$ & $\begin{array}{l}-0.1973 * \\
(0.1046)\end{array}$ & $\begin{array}{l}-0.0697^{*} \\
(0.0376)\end{array}$ & $\begin{array}{c}-0.2842 * * \\
(0.1224)\end{array}$ & $\begin{array}{l}-0.2018^{*} \\
(0.1113)\end{array}$ & $\begin{array}{l}-0.0207 \\
(0.0365)\end{array}$ \\
\hline Institutional Ownership & $\begin{array}{c}1.6531 * * * \\
(0.4391)\end{array}$ & $\begin{array}{c}1.2969 * * * \\
(0.3908)\end{array}$ & $\begin{array}{l}0.2414 * \\
(0.1409)\end{array}$ & $\begin{array}{c}1.5737 * * * \\
(0.4702)\end{array}$ & $\begin{array}{c}1.2684 * * * \\
(0.4121)\end{array}$ & $\begin{array}{c}0.1105 \\
(0.1537)\end{array}$ \\
\hline Group Firm & $\begin{array}{c}0.1784 \\
(0.1222)\end{array}$ & $\begin{array}{c}0.1553 \\
(0.1053)\end{array}$ & $\begin{array}{c}0.0299 \\
(0.0341)\end{array}$ & $\begin{array}{c}0.1279 \\
(0.1335)\end{array}$ & $\begin{array}{c}0.1085 \\
(0.1141)\end{array}$ & $\begin{array}{c}0.0120 \\
(0.0320)\end{array}$ \\
\hline Firm Size & $\begin{array}{c}0.3516 * * * \\
(0.0335)\end{array}$ & $\begin{array}{c}0.3492 * * * \\
(0.0351)\end{array}$ & $\begin{array}{c}0.0671 * * * \\
(0.0205)\end{array}$ & $\begin{array}{c}0.3516 * * * \\
(0.0357)\end{array}$ & $\begin{array}{c}0.3540 * * * \\
(0.0377)\end{array}$ & $\begin{array}{c}0.0410 * * \\
(0.0178)\end{array}$ \\
\hline Firm Risk & $\begin{array}{l}-0.1904 \\
(0.1951)\end{array}$ & $\begin{array}{l}-0.0907 \\
(0.1955)\end{array}$ & $\begin{array}{l}-0.0645 \\
(0.1603)\end{array}$ & $\begin{array}{l}-0.2956 \\
(0.2028)\end{array}$ & $\begin{array}{l}-0.2104 \\
(0.1956)\end{array}$ & $\begin{array}{c}0.0205 \\
(0.1965)\end{array}$ \\
\hline Market to Book Ratio & $\begin{array}{l}-0.0066 \\
(0.0086)\end{array}$ & $\begin{array}{l}-0.0073 \\
(0.0096)\end{array}$ & $\begin{array}{c}0.0016 \\
(0.0032)\end{array}$ & $\begin{array}{l}-0.0024 \\
(0.0082)\end{array}$ & $\begin{array}{l}-0.0046 \\
(0.0092)\end{array}$ & $\begin{array}{c}0.0014 \\
(0.0027)\end{array}$ \\
\hline Firm Age & $\begin{array}{c}0.0084 * * \\
(0.0035)\end{array}$ & $\begin{array}{c}0.0063 * * \\
(0.0031)\end{array}$ & $\begin{array}{c}0.0006 \\
(0.0008)\end{array}$ & $\begin{array}{c}0.0081 * * \\
(0.0038)\end{array}$ & $\begin{array}{c}0.0054 \\
(0.0034)\end{array}$ & $\begin{array}{l}-0.0005 \\
(0.0008)\end{array}$ \\
\hline Change of CEO & $\begin{array}{l}-0.1156 \\
(0.0757)\end{array}$ & $\begin{array}{l}-0.1116 \\
(0.0696)\end{array}$ & $\begin{array}{c}0.0308 \\
(0.0387)\end{array}$ & $\begin{array}{c}-0.1618 * * \\
(0.0812)\end{array}$ & $\begin{array}{c}-0.1518 * * \\
(0.0751)\end{array}$ & $\begin{array}{c}0.0278 \\
(0.0369)\end{array}$ \\
\hline $\begin{array}{l}\text { Observations } \\
\text { R-squared }\end{array}$ & $\begin{array}{c}1,508 \\
0.4954\end{array}$ & $\begin{array}{c}1,508 \\
0.6216\end{array}$ & $\begin{array}{c}1277 \\
----\end{array}$ & $\begin{array}{c}1,508 \\
0.4681\end{array}$ & $\begin{array}{c}1,508 \\
0.5830\end{array}$ & $\begin{array}{c}1,277 \\
----\end{array}$ \\
\hline $\begin{array}{l}\text { Arellano-Bond } \\
\mathrm{AR}(1) \text { in Diff. }(\mathrm{m} 1) \mathrm{p} \text {-value } \\
\mathrm{AR}(2) \text { in Diff. }(\mathrm{m} 2) \mathrm{p} \text {-value }\end{array}$ & $\begin{array}{l}--- \\
----\end{array}$ & ---- & $\begin{array}{l}0.000 \\
0.764\end{array}$ & ---- & ---- & $\begin{array}{l}0.000 \\
0.377\end{array}$ \\
\hline $\begin{array}{l}\text { Over identification test } \\
\text { Sargan test p-value } \\
\text { Hansen J statistic p-values }\end{array}$ & ---- & ---- & $\begin{array}{l}0.149 \\
0.788\end{array}$ & ---- & --- & $\begin{array}{l}0.358 \\
0.489\end{array}$ \\
\hline $\begin{array}{l}\text { Dependent variable is log of con } \\
\text { is measured by current market } \\
\text { shares held by the largest shareh } \\
\text { measured by number of directors } \\
\text { variable taking value one if CE } \\
\text { institutions. Group Firm is a dum } \\
\text { assets, Firm Risk is measured by } \\
\text { divided by book value per share, } \\
\text { term of dummy variable taking } \\
\text { Robust standard errors in parentl } \\
\text { Windmeijer-corrected Standard } \\
* * * p<0.01, * * p<0.05, * p<0.1\end{array}$ & $\begin{array}{l}\text { ion, Return on } \\
\text { s dividend div } \\
\text { Family Owner } \\
\text { rd, Board Inde } \\
\text { so chairman b } \\
\text { iable taking va } \\
\text { rd deviation o } \\
\text { ge is number o } \\
\text { if CEO is repla } \\
\text { r pooled and f } \\
\text { parentheses } \mathrm{f}\end{array}$ & $\begin{array}{l}\text { sets is measured } \\
\mathrm{d} \text { by previous ye } \\
\mathrm{p} \text { is a dummy va } \\
\text { dence is measur } \\
\mathrm{d} \text { of directors, I } \\
1 \text { if a firm is affi } \\
\text { onthly stock retu } \\
\text { ars of establishn } \\
\text { during the year } \\
\text { effect models } \\
\text { lynamic panel m }\end{array}$ & $\begin{array}{l}\text { y earnings bef } \\
\text { market price } \\
\text { able taking va } \\
\text { by ratio of nor } \\
\text { titutional Ow } \\
\text { ated with a gro } \\
\text { s over the fisc } \\
\text { nt of the firm a } \\
\text { nd number of } \\
\text { el }\end{array}$ & $\begin{array}{l}\text { est and taxes di } \\
\text { ke, Ownership } \\
\text { for family firm } \\
\text { ive directors to } \\
\text { is measured by } \\
\text { ero otherwise, } \\
\text { Market to Bool } \\
\text { ned in annual r } \\
\text { awing remuner }\end{array}$ & $\begin{array}{l}\text { led by total asse } \\
\text { ncentration is } \mathrm{m} \\
\text { and zero otherwi } \\
\text { ard size, CEO D } \\
\text { ercentage of tot } \\
\mathrm{m} \text { Size is measu } \\
\text { atio is measurec } \\
\text { orts, Change of C } \\
\text { on during the ye }\end{array}$ & $\begin{array}{l}\text { Market Retur } \\
\text { sured by votin } \\
\text { Board Size i } \\
\text { lity is a dumm } \\
\text { shares held b } \\
\text { d by log of tota } \\
\text { y market valu } \\
\text { O is interactio }\end{array}$ \\
\hline
\end{tabular}

